\title{
Gastropod diversity in the Riparian Zone of Balingasay River, Bolinao, Pangasinan, Philippines
}

\author{
Rainier Ulrich Velasco ${ }^{1,2}$, Mark Louie Lopez $z^{3,4}$, E Mark Kevin Devanadera ${ }^{* 1,5}$ \\ ${ }^{1}$ The Graduate School, University of Santo Tomas, Manila; 'Department of Biology, Pamantasan ng \\ Lungsod ng Maynila, Manila; ${ }^{3}$ Biodiversity Program, Taiwan International Graduate Program, \\ Biodiversity Research Center, Academia Sinica and National Taiwan Normal University; ${ }^{4}$ Department \\ of Life Science, National Taiwan Normal University; ${ }^{5}$ Department of Biochemistry, Faculty of \\ Pharmacy, University of Santo Tomas, Manila
}

\begin{abstract}
Balingasay River in the Philippines is a protected seascape with rich mangrove areas that support diverse life forms. Gastropod diversity in an ecosystem also represents the status of environment, richness of biodiversity, and the diversity of life forms in the river. This study aims to determine the composition of gastropods and its diversity in the Balingasay River. Gastropod composition, abundance and diversity were observed by analyzing snail samples observed and collected from two sites along the riparian zone of Balingasay River. A total of seven marine species of gastropods were identified from the 253 collected individuals. It was noted that species under family Neritidae and Potamididae are abundant within the sampled areas. Neritina turrita was found to be most abundant with $59.69 \%$ of the total gastropods collected and followed by Littoraria scabra with $11.86 \%$ composition. In addition, seaward portion of the river has the higher snail diversity and high species richness compared to the inward area. While the inward area has high dominance compared to the seaward area of the river. In summary, marine species are found to be present in the estuarine to freshwater environment which indicates the ecological diversity of the mangrove and estuarine ecosystem of the river.
\end{abstract}

Keywords: diversity, mangrove snails, freshwater, brackish, Balingasay River

\section{INTRODUCTION}

Riparian areas with different water tributaries can make up to $80 \%$ of the total area of a given watershed [1] and correspond to an important interface between water and land-based ecosystems. One of the organisms found in this area are macroinvertebrates, which are small

*To whom correspondence should be addressed: marklouiedlopez@gmail.com; rain_1206@hotmail.ph; markkevindevanadera@yahoo.com animals living in rocks, logs, sediments, debris, and aquatic plants [2]. These macroinvertebrates are sensitive to their environmental conditions thus it might require clean and oxygenated environment. Their presence provides a bioindicator of the water quality of the environment [2]. The aquatic ecosystem condition could be assessed through determining the various relationship of abiotic and biotic indicators such as the land usage within the ecosystem or by the community, water 
quality, riparian vegetation, and aquatic plant and animal biodiversity [3, 4].

Macroinvertebrates are very important components in the freshwater biome since they are commonly link as the food for higher aquatic organisms, their species diversity is controlled by their productivity, habitat, and species interaction, and environmental factors [2]. There are an estimated 70,000 molluscan species around the globe [5], and 22,000 species are held to be present in the Philippines [6]. Mollusks which are the second most diverse invertebrates in the Philippines are mostly bivalves and gastropods [6]. Gastropods are torted, asymmetrical mollusks, usually with a spirally coiled shell. Their asymmetric internal anatomy resulted from torsion, which occurs in the first few hours of larval development [7]. Despite of their abundance, only few publications of gastropod listings were conducted, especially in the Philippines. However, these researches were mostly focused in marine environments and there are only few concerning the distribution of gastropods in freshwater environments.

Balingasay River is known as one of the cleanest rivers in the Philippines. The river is fed by Quibuar Spring, Bolinao Falls and several small tributaries. Its riparian zone is set aside as a protected seascape consisting of mangrove areas, stretches of nipa palms and balete trees hanging into the water. The river's unique and dynamic ecotone supports a great abundance of wildlife and fulfilling numerous ecological roles, but only few systematic studies have been executed on Balingasay’s rich biodiversity.

This study intended to produce data on the taxonomic distribution and diversity of gastropods in Balingasay River, Bolinao, Pangasinan. This survey of freshwater gastropods species could be a relevant tool for documenting taxonomic data, which could provide a comprehensive summary on the gastropod's distribution in Balingasay River for potential economic, scientific and even medical applications.

\section{EXPERIMENTAL}

Species survey. Four sampling area were established along the Balingasay River, Bolinao, Pangasinan (Fig. 1). The first two sampling sites (11951'18” N and 1621'23”' E) were situated in seaward area while another two sampling sites (119'51'38' N and 16 20'18' E) were in the inland part of the river. One hundred (100) meter long transect line were established in between of the two sampling sites in seaward and inland part of Balingasay River to determine the longitudinal profile of the river. The substrate type and vegetation characteristic in each site were also noted.

Sampling and systematic surveys were done based on the protocol of Flores and Zafaralla [8] and Fontanilla et al. [9] wherein $1 \times 1 \mathrm{~m}$ plot was randomly placed along the transect line. A maximum of 10 min per plot was allotted to search for mollusks. On each quadrat, snails were collected by hand picking through the upper surface of sediment, water and vegetations. Only live snails were considered in the study. Samples were placed in bottles and preserved using $70 \%$ v/v ethyl alcohol.

Taxonomic identification. Initial identification and classification of samples was performed using Badel and Riedel [10], Carpenter and Niem [7], Leal [11], Perez et al. [12], Dance [13], Ghasemi et al. [14], Green et al. [15], Lamprell and Healy [16], Lamprell and Whitehead [17], Poppe [18, 19], Rosenberg [20], Springsteen and Lebrera [21], Berdach [22], and Reid [23] as references. Online databases for marine and freshwater gastropods were also utilized. Voucher specimen from each species were initially identified and prepared for the verification with an expert on gastropods. Voucher specimens were verified by an expert in Mollusca in the Zoology Division of the 
National Museum of the Philippines; the specimens were assigned by corresponding catalog numbers based on the sampling site and were deposited in the Philippine National Museum (Manila, Philippines).

Measurement of diversity indices. Different diversity indices were used to obtain the estimation of species diversity, dominance, and richness of gastropods present in the study site. The number of taxa, Shannon-Weiner index ( $\left.\mathrm{H}^{\prime}\right)$, Simpson's diversity index (1-D), dominance (D), and Margalef's index were considered in characterizing the gastropod community present in Baligasay River. All the indices were evaluated using the Paleontological Statistics ver. 1.88 software [24].

\section{RESUlTS}

A total of 250 individual gastropods were collected from the sample sites shown in Fig. 2. There were seven species of gastropods belonging to three families, which include Neritidae, Littorinidae, and Potamididae. Habitats for these species ranges from marine, brackish and freshwater environment. In the seaward site of the river (Fig. 1, $1^{\text {st }}$ sampling site), large area coverage of mangrove ecosystem was observed, and the land was composed of sand to rocky part with many litters of leaves and branches from the trees and mangroves. On the hand, the inland site (Fig. 1, $2^{\text {nd }}$ sampling site) is characterized by muddy substrate, lesser area

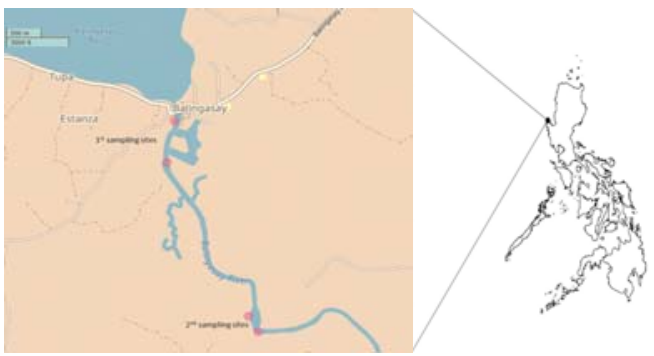

Figure 1. Map of the Balingasay River showing the two sampling sites. LG - Lingayen Gulf, BR Balingasay River, S1 - seaward transect and S2 inland transect.

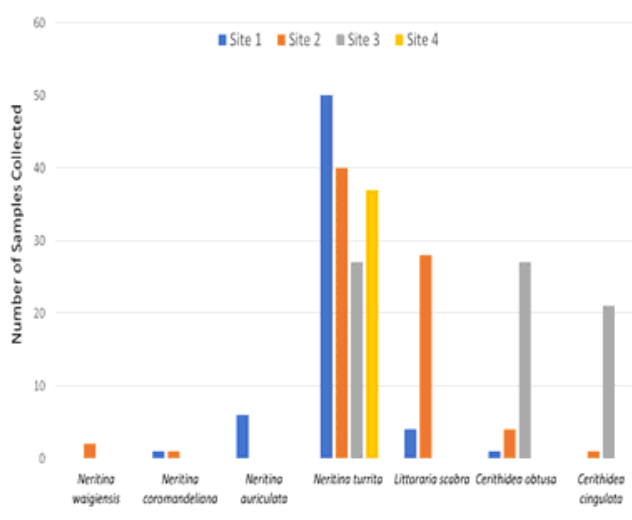

Figure 2. Number of samples collected per species in each sampling sites (seaward and inland).

coverage of mangroves and nipa, many channels of freshwater from spring and minimal litters of leaves. Ecosystem structure of the sampling sites has direct effect in the composition, abundance and diversity of the gastropods in a specific area [9]. The presence of both marine and freshwater species within the sampled areas suggests that it is an estuarine ecosystem.

\section{Class: Gastropoda}

Order: Cycloneritimorpha

SuperFamily: Neritoidea

Family: Neritidae

Family Neritidae possess heavy, semi-globose, dextrally coiled shells that are often smooth and glossy and thinner than their marine relatives. The columella forms a plate that partially extends across the aperture. This plate is elaborated with finely serrate denticles. The operculum is thick and calcareous and bears pegs (apophyses) to which muscles of the foot attach and aid in closing and locking the operculum in place. Like the aperture, the operculum is half-moon shaped and is capable of completely sealing the aperture. Individuals possess a single monopectinate gill in the mantle cavity on the left. Many nerites are algal grazers and possess a rhipidoglossate radula with numerous, brushlike marginal teeth. The sexes are separate and 
males possess a penis on the cephalic lappet to the left of the right cephalic tentacle. A merely 110 species of freshwater gastropods belonging to this family are validly described in the whole world and has an approximate of 20 to 45 valid species in this family are found in the South East Asia region [25].

Neritina waigiensis (Lesson, 1831) (PNM 041066). Synonyms: Neritina communis (Quoy HE \& Gaimand JP, 1832). In reference to the Worldwide Mollusc Species Database, this species has been observed in provinces in Visayas and Mindanao Region of the Philippines and no record yet in the Luzon Island (Fig. 3A).

\section{Neritina (Vittina) coromandeliana (Sowerby} GBII, 1832) (PNM 041067). Synonyms: Nerita parallela (Roding PF, 1798); Neritina strigillata (Recluz, 1850); Neritina pulcherrima (Mousson, 1857); Neritina triangularis (Morch, 1852); Neritina serrulata (Recluz, 1842); Neritina ziczac (Auct. non Lamarck, 1822). This species has records in Bohol Island, Cebu Island and some part of Leyte in the Philippines; it was also observed in some part of Asia like Thailand, Indonesia, Japan and in some part of Micronesia according to the Worldwide Mollusk Species Database (Fig. 3B).
Neritina auriculata (Lamarck, 1826) (PNM 041065). Synonyms: Nerita dubia (Turton, 1932); Nerita tomlini (Turton, 1933). According to the Worldwide Mollusk Species Database, this species has records in Negros, Philippines, Indonesia and other parts of Japan (Fig. 3C).

Neritina turrita (Gmelin, 1971) (PNM 041064). A species commonly found in brackish and freshwater. Shell rather thin but solid, elongateovate in outline, with an elevated, conical spire and large, inflated body whorl. Spire often eroded at the apex, whorls rapidly increasing in size, convex but slightly concave just below the strongly embracing suture. Outer surface smooth except for fine axial growth marks, with a shiny, thick and adherent periostracum which is covered by a microscopical pattern of crowded, tiny, cancellate lines. Outer lip of the aperture thin, sharp and smooth, not toothed inside. Columellar shield thick and smooth, with numerous, small teeth along its inner edge. Operculum finely granulose, with a rounded, protruding knob near anterior end, in addition to the projecting peg of the inner margin. Maximum shell length $3.5 \mathrm{~cm}$, commonly to 2.5 cm (Fig. 3D). Distributed in countries near the Eastern part of the Indian Ocean and the tropical

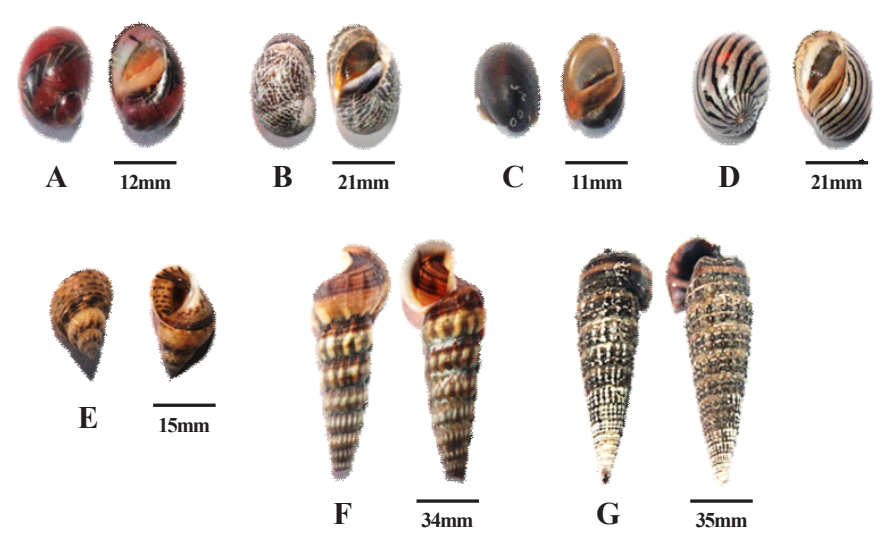

Figure 3. Shell morphology of (A) Neritina waigiensis (Lesson, 1831) (PNM 041066), (B) Neritina (Vittina) coromandeliana (Sowerby GBII, 1832) (PNM 041067), (C) Neritina auriculata (Lamarck, 1826) (PNM 041065), (D) Neritina turrita (Gmelin, 1971) (PNM 041064), (E) Littoraria scabra (Linnaeus C, 1758) (PNM 041070), (F) Cerithidea obtusa (Lamarck JBPA de, 1822) (PNM 041068), and (G) Cerithidea cingulata (Gmelin JF, 1791) (PNM 041069) 
West Pacific, from the Andaman Sea to eastern Polynesia; north to southern Japan, and south to southern Indonesia and Melanesia. According to Worldwide Mollusk Species Database, this species has been abundant in the whole Philippines from Luzon up to Mindanao. This species is also abundant in the countries that surround the South China Sea except for Japan and Micronesia who have also some records of this species in their coastal area.

\section{Class: Gastropoda}

\section{Order: Littorinimorpha}

\section{SuperFamily: Littorinoidea}

\section{Family: Littorinidae}

Family Littorinidae have ovate-conical shells, usually strong and without an umbilicus. Smooth outer surface with spiral or nodular sculpture. Periostracum absent. Aperture rounded, porcelaneous, without a siphonal canal. Columellar smooth or with a tooth-like swelling. Operculum thin and corneous, with relatively few spiral coils and either ovate with a lateral nucleus or rounded with a subcentral nucleus. Head with a short snout and conical tentacles bearing eyes on small swellings at their outer bases. Foot rather strong, the two sides of which can move independently. Based on Miloslavich et al. [26], this family are more diverse in terms of number of species in between the northern hemisphere and southern hemisphere where tropical countries are located.

Littoraria scabra (Linnaeus C, 1758) (PNM 041070). Synonyms: Buccinum lineatum (Gmelin JF, 1791; Lottorina novahiberniae (Lesson RP, 1831); Turbo striatus (Linnaeus C, 1838); Littorina foliorum (Gmelin, 1791); Littoraria pallescens erronea (Nevill, 1885); Littoraria scabrapunctata (Philippi, 1847); Littoraria scabrarubra (Philippi, 1847); Littorina intermedia strigata (Philippi, 1846). A marine species with thin but solid shell, with a tall, conical spire and low sculpture. Spire whorls are convex, with a narrowly channeled, incised suture, numerous, fine, low and flattened spiral cords and a raised, rounded cord determining a well-marked angle at periphery. Outer lip of aperture thin and smooth. Columella smooth, has a straight anterior which meet in the basal end of shell at an acute angle. Operculum ovate, with a few spiral coils and lateral nucleus. Outside of shell whitish to pale brown, with dense pattern of dark brown and black dashes mostly on spiral cords, generally more or less aligned into oblique axial stripes. Peripheral cord usually with conspicuous white gaps between the dashes. Aperture pale yellow to whitish, with the outer dark pattern showing through (Fig. 3E). Columella white, sometimes stained brown or purple. Maximum shell length $4.4 \mathrm{~cm}$, commonly to $3 \mathrm{~cm}$ and widespread in the Indo-West Pacific, from East Africa, including Madagascar and the Red Sea, to eastern Polynesia; north to southern Japan and Hawaii, and south to southern Queensland and New Caledonia. According to the Worldwide Mollusk Species Database, this species was widely distributed in Cebu, Negros, Bohol, Masbate and Bataan in Philippines though there was record in Bataan, there was no record in other parts of Northern Luzon. This species was also widely distributed in Malaysia, Thailand, Vietnam and Indonesia.

\section{Class: Gastropoda \\ Order: Sorbeoconcha \\ SuperFamily: Cerithioidea}

Family: Potamididae

Family Potamididae have a thick shell and solid, tapering, high-conical, with many flattened or slightly convex spire whorls. Sculpture generally coarse, with spiral grooves or cords and often axial ribs, giving a reticulated to nodular aspect. Axial varices sometimes present. Periostracum usually well developed, brownish to corneous. Aperture relatively small, with a short and deep anterior siphonal canal. Outer lip often thickened and more or less flaring. Operculum rounded, corneous, with many spiral coils and a subcentral nucleus. Head with a pair of tentacles, abruptly narrowing distally and bearing eyes at or above their thickened bases. Foot rounded 
in front and obtuse behind. Based on Miloslavich et al. [26], this superfamily is more diverse in terms of number of species in the northern hemisphere and has small number of species in between the northern and southern hemisphere where tropical countries are located.

Cerithidea obtusa (Lamarck JBPA de, 1822) (PNM 041068). Synonym: Cerithidea lineolata (Griffith \& Pidgeon, 1834). A species commonly found in marine to brackish water environments. Its shell is medium sized, with a moderately high conical spire and broad rounded base. Spire whorls convex, with moderately deep suture, six or seven rounded spiral cords crossed by stronger, relatively broad axial ridges, and forming a pattern of more or less sharp nodules. Apical part of the spire always broken off. Body whorl wide, rounded at periphery, with the axial ridges fading away and with 12 to 15 fine spiral cords on the base. An indistinct axial varix sometimes present on left ventral side of body whorl. Aperture wide, subcircular in outline, without a wing-like expansion at posterior end. Outer lip thickened and flaring, with a tongueshaped anterior end produced over the siphonal canal. Columella narrow, posteriorly interrupted, without internal spiral ridges. Anterior siphonal canal short, open and oblique. Its color is brown or dull purplish brown outside of shell, with a brighter zone just below the suture; base plain brown or yellowish with a darker brown zone. Aperture brownish, outer lip of mature specimen cream (Fig. 3F). Maximum shell length $6 \mathrm{~cm}$, commonly to $5 \mathrm{~cm}$ and distributed in Indo-West Pacific, from Madagascar and India to eastern Indonesia; north to the Philippines and south to northern Queensland.

Cerithidea cingulata (Gmelin JF, 1791) (PNM 041069). Synonyms: Cerithidea microptera (Kiener LC, 1842); Cerithidea terebella (Gmelin, 1791); Cerithidea muricata (Sowerby, 1855); Cerithidea radula (Ferussac, 1866). Abundant on mud flats near mangroves and in brackish or supersalted fishponds. Its shell with both axial and spiral sculpture. Columella without spiral ridges and an outer lip posteriorly expanded in a flaring, wing-like process (Fig. 3G). Usually living in the upper bottom layer of mud which is almost liquid. Extensively collected for food and to make lime in the Philippines. Indo-West Pacific, from India and Sri Lanka to Papua New Guinea; north to Japan and south to central Queensland.

\section{Discussion}

Both freshwater and marine species were gathered in the two sites. The Table below shows the frequency and relative abundance of gastropods surveyed in Balingasay River. Neritina turrita comprises of $59.69 \%$ of the total gastropods collected, and Littoraria scabra (11.86\%). These gastropods were also the abundant species in the seaward site while Cerithidea obtusa dominates the inland area. Table 1 shows that a higher number of taxa $(S=13)$ were found in the seaward area than the inland site $(S=6)$. Likewise, species richness was found to be high in seaward area $(d=4.066)$ than inland area $(d=1.843)$. High value of species richness in the seaward site is evidently supported by the occurrence of a high number of taxa present in the said station. In terms of the dominance, a higher value was recorded in the inland area $(D=0.35)$ compared to the seaward area with $D=0.24$. The high value of dominance in the inland area indicates that there is a tendency that one species could dominate the community. Conversely, the noted Shannon-wiener and

Ecological indices for the two sampling site
from Balingasay River (Values on each row
with same superscript are not significantly
different from each other, $\alpha=0.05)$.

\begin{tabular}{l|c|c}
\hline \multicolumn{1}{c|}{ Indices } & Estuarine & Inland \\
\hline Dominance & $0.24^{\mathrm{a}}$ & $0.35^{\mathrm{a}}$ \\
\hline Shannon $\mathrm{H}$ & $1.69^{\mathrm{a}}$ & $1.23^{\mathrm{a}}$ \\
\hline Simpson index & $0.76^{\mathrm{a}}$ & $0.65^{\mathrm{a}}$ \\
\hline Evenness $\mathrm{e}^{\wedge} \mathrm{H} / \mathrm{S}$ & $0.42^{\mathrm{a}}$ & $0.57^{\mathrm{a}}$ \\
\hline Margalef & $2.43^{\mathrm{a}}$ & $1.06^{\mathrm{a}}$ \\
\hline
\end{tabular}


Simpson's indices in seaward area is greater compared to the inland portion. These two indices measure the diversity of snails in the two sites. The higher values of these indices in seaward site suggest that the diversity of gastropods is highly characterized by the total species present in the site.

Irma and Sofyatuddin [27] elaborated that there is a connection between the size of the substrate, its carbon content and its oxygen carrying capacity. Sandy soil enables good oxidation for the water and makes high dissolved oxygen but less organic content. On this note, the high density and diversity of the snails in seaward site is likely dependable on the ecosystem structure of the area. It was noted that the seaward site was composed of sandy to muddy part of substrate, high diverse of mangrove forest and many litters of leaves and branches which was the best living condition for the most gastropods.

Diversity of gastropods is highly affected by the vegetation area, substrate type, dissolved organic matter, and the physicochemical characteristics of water in the area $[27,28]$. The higher diversity of gastropods observed in seaward site is due to the higher coverage of vegetation area, sandy to rocky substrate and most of all, the high organic matter present in the substrate. According to Irma and Sofyatuddin [27] and Bouchet et al. [29], organic matter in substrate is highly dependent to the litters falling in the surrounding vegetation area. Sukarjo [30] found that high quantities of carbon organic matter were from high density of trees because the fallen litter of mangrove leaves contributes significantly to the higher organic matter in the soil. In addition, Plaziat [28] stated types of substrates had strong relationship with nutrient in sediment and stated that the substrate condition influences the development of biotic communities, where muddy with a little clay is a desirable substrate for gastropods.
Another factor to consider is the physicochemical condition of the water within the area [31]. Though water temperature is rarely a limiting factor for snails living within their natural geographic area, other factors such as dissolve oxygen, $\mathrm{pH}$, and salinity have great effect on snail diversity and survival [32]. Gastropods use dissolved oxygen in the water for their metabolic activities and in that note; dissolved oxygen can be a limiting factor for their survival. The salinity and $\mathrm{pH}$ value in water is also important for diversity of gastropods since it directly affect development of snails [31, 33].

\section{Conclusion}

Results from this study provides the taxonomic record of gastropods present in Balingasay River. It was found that both freshwater and marine species of gastropods are present within the sites demonstrating the estuarine nature of the river. The collected species were able to adapt to the constant changes in salts due to water movement during tides.

\section{AcKnowledgment}

We would like to thank Dr. Rey Papa for his help, advises and contribution to this study. We would like also to thank Ms. Vivian Ang of the Philippine National Museum for her expertise in helping us to identify the species of gastropods collected and for her assistance in storing our voucher specimen in the Philippine National Museum. This research work was part on our Advanced Ecology class in the Graduate School.

\section{REFERENCES}

[1] Foster AD \& Ziegltrum J. Riparian-associated Gastropods in Western Washington: Community Composition and the Effects of Forest Management. Northwest Science 2013, 87(3):243-256. 
[2] Tampus AD, Tobias EG, Amparado RF, Bajo L, \& Sinco AL. Water Quality Assessment using Macroinvertebrates and Physico-chemical Parameters in the Riverine System of Iligan City, Philippines. AES Bioflux 2012, 4(2):59-68.

[3] Pan Y, Herlihy A, Kaufmann P, Wigington J, Sickle $\mathrm{J}$, \& Moser T. Linkages among Land use, Water Quality, Physical Habitat Conditions and Lothic Diatom Assemblages: A Multi-Spatial Scale Assessment. Hydrobiologia 2009, 515:59-73.

[4] Rios S \& Bailey R. Relationship between Riparian Vegetation and Stream Benthic Communities at Three Spatial Scales. Hydrobiologia 2006, 553:153-160.

[5] International Union for the Conservation of Nature (IUCN). 2004 IUCN Red List of Threatened 2004.

[6] Ong PS, Afuang LE, \& Rosell-Ambal RG. Philippine Biodiversity Conservation Priorities: A Second Iteration of the National Biodiversity Strategy and Action Plan: Final Report, 114p. (Philippine Biodiversity Conservation Priority setting Program (PBCPP), 2002).

[7] Carpenter KE \& Niem VH. The living marine resources of the Western Central Pacific. FAO species identification guide for fishery purposes 1998, 1:363-646.

[8] Flores MJL \& Zafaralla MT. Macroinvertebrates Composition, Diversity, and Richness in Relation to the Water Quality Status of Mananga River, Cebu, Philippines. Philippine Science Letters 2012, 5(2):103-113.

[9] Fontanilla IKC, Batomalaque GA, Arce BPC, \& Hernandez MBM. Survey and Spatial Distribution of Shoreline Malacofauna in Grande Island, Subic Bay. Philippine Journal of Science 2010, 139(2):149-159.

[10] Badel K \& Riedel F. Ecological zonation of gastropods in Matutinao River (Cebu, Philippines), with focus on their life cycles. Annales de Limnologie-International Journal of Limnology 1998, 34(2):171-191.

[11] Leal JH. Gastropods. The Bailey-Matthews Shell 2000, 100-147.

[12] Perez KE, Clark SA, \& Lydeard C. Freshwater Gastropod Identification Workshop: A Primer to Freshwater Gastropod Identification, 1-61pp. (Freshwater Mollusk Conservation Society, University of Alabama, Tuscaloosa, Alabama. 2004).

[13] Dance SP. The encyclopedia of shell-a guide to the world's shell, 288p. (London: Blandford Press, 1974).
[14] Ghasemi S, Zakaria M, \& Mola Hoveizeh N. Abundance of mollusks (Gastropods) at mangrove forests of Iran. Journal of American Science 2011, 7(1): 660-669.

[15] Green J, Reichelt-Brushett A, \& Jacobs SWL. Investigating Gastropod Habitat Associations in Saltmarsh. (Wetlands, Australia, 2011, 25(1):25-37.

[16] Lamprell K \& Healy J. Bivalves of Australia (Vol 2), 182pp. (Bathurst, New South Wales: Crawford House, 1998).

[17] Lamprell K \& Whitehead T. Bivalves of Australia (Vol. 1), 182pp. (Bathurst, New South Wales: Crawfoed House, 1992).

[18] Poppe GT. Philippine Marine Mollusks (Vol. 1): Gastropoda, 758pp. (Germany: Conchbooks, 2008a).

[19] Poppe GT. Philippine Marine Mollusks (Vol. 2), 849pp. (Germany: Conchbooks, 2008b).

[20] Rosenberg G. A biotic database of Indo-Pacific Marine Mollusks. (Philadelphia: The Academy of Natural Sciences, 2010).

[21] Springsteen FJ \& Leobrera FM. Shells of the Philippines, 377p. (Manila: Carfel Seashell Museum, 1986).

[22] Berdach JT. Inventory of marine gastropods in the Man and the Biosphere (MAB) Reserve area, Puerto Galera, Oriental Mindoro, Philippines. Philippine Journal of Biology 1981, 10(1):95108.

[23] Reid DG. The Littorinid Mollusks of Mangrove Forests in the Indo-Pacific Region: The Genus Littonaria, 27pp. (London: British Museum Natural History, 1986).

[24] Hammer O, Harper DAT, \& Ryan PD. PAST: Paleontological Statistic Software Package for Education and Data Analysis. Paleontological Electronica 2001, 4(1):1-9.

[25] Strong EE, Gargominy O, Ponder WF, \& Bouchet P. Global Diversity of Gastropods (Gastropoda; Mollusca) in Freshwater. Hydrobiologia 2008.

[26] Miloslavich P, Cruz-Motta JJ, Klein E, Iken K, Weinberger V, Konas B, Trott T, Pohle G, Bigatti G, Benedetti-Cecchi L, Shirayama Y, Mead A, Palomo G, Ortiz M, Gobin J, Sardi A, Diaz JM, Knowlton A, Wong M, \& Peralta A. Large-Scale Spatial Distribution Patterns of Gastropod Assemblages in Rocky Shores. PLoS ONE 2013, 8(8). 
[27] Irma D \& Sofyatuddin K. Diversity of gastropods and bivalves in mangrove ecosystem rehabilitation areas in Aceh Besar and Banda Aceh districts, Indonesia. Aquaculture, Aquarium, Conservation \& Legislation 2012, 5(2):55-59.

[28] Plaziat JC. Mollusk distribution in the Mangal. Hydrobiology of the Mangal, pp. 111-143. (The Hague: Dr W. Junk Publishers, 1984).

[29] Bouchet P, Lozouet P, Maestrati P, \& Heros V. Assessing the magnitude of species richness in tropical marine environments: exceptionally high numbers of mollusks at a New Caledonia site. Biological Journal of the Linnean Society 2002, 75(4):421- 436.
[30] Sukarjo S. Soils in the mangrove forests of the Apar Nature Reserve, Tanah Grogot, East Kalimantan, Indonesia. Southeast Asian Studies 1994, 32(3):385-398.

[31] Vallejo BM. The biogeography of Philippine marine mollusks. Loyola Schools Review 2001, 1:5877.

[32] Lydreard C, Cowie RH, \& Pouder WF. The global decline of non-marine mollusks. Bioscience 2004, 54(4):321-329.

[33] Alfred JB, Varshney RK, \& Ghosh AK. An assessment manual for faunal biodiversity in South Asia. Biodiversity in South Asia (SACEP/ NORAD Publication Series) 1997, 1:181. 